\title{
Assessing the Nigerian Federal Government's Financial Commitments to Its Education Rights Obligations
}

\author{
Chukwuemeka 0. Onyimadu \\ Department of Research and Training, National Institute for Legislative Studies, National Assembly Abuja, Abuja, Nigeria \\ Email: onyimadu.chukwuemeka@nils.gov.ng
}

How to cite this paper: Onyimadu, C. O. (2020). Assessing the Nigerian Federal Government's Financial Commitments to Its Education Rights Obligations. Modern Economy, 11, 475-494.

https://doi.org/10.4236/me.2020.112035

Received: January 10, 2020

Accepted: February 18, 2020

Published: February 21, 2020

Copyright $\odot 2020$ by author(s) and Scientific Research Publishing Inc. This work is licensed under the Creative Commons Attribution International License (CC BY 4.0).

http://creativecommons.org/licenses/by/4.0/

\begin{abstract}
The paper provides insights on the (mis)match between the Federal Government's Appropriations for education in relation to fulfilling its obligations towards education rights. Using budgeted expenditure on education from 2016 to 2018, the paper found that the Federal Government's financial commitments have not shown progressive achievements in meeting up with its education obligations. Also, in making use of available resources, priority has leaned towards non-Economic, Social and Cultural rights over education rights. The paper advocated action plans for both the legislature and civil society that borders on policy review pressure for equitable funding of all levels of education and possible litigation.
\end{abstract}

\section{Keywords}

Education Rights, Education Obligation, Expenditure on Education, Public Finance

\section{Introduction}

Globally, education is a fundamental human right, a key driver of inclusive development and an instrument for effectively alleviating the incidence of absolute poverty, reducing both gender and health inequalities and ensuring the overall welfare advancements of the society (Psacharopoulos \& Patrinos, 2018). According to Ball (1998), education as an investment ensures significantly larger income returns, which exposes the individual to equal economic opportunities, increased financial earnings and an incentive for improved health status. For societies, education is a determining factor of both medium to long term economic 
growth, sufficiently strengthen institutions, and foster social cohesion (Auld, Rappleye, and Morris, 2019).

In accordance with the established economic relevance of education to the society, the Universal Basic Education Act (UBE) 2004 guarantees the right of every child to compulsory, free basic education from Primary to junior secondary education, provided by every government. Despite the guarantees of the UBE Act, about 10.5 million children in Nigeria between the age brackets 5 - 14 years are not in school (UNICEF, 2019, September 13) ${ }^{1}$. More severe is the statistic that indicates that only $61 \%$ of $6-11$ year olds are regular in attending primary school, with only $35.6 \%$ of children within the age bracket 36 - 59 months had received any form of early childhood education. These negative education indicators are more severe in the North East region of Nigeria, with a significant higher incidence of education inequalities, especially for the girl child. Also evident poverty-related education marginalization and education deprivation driven by factors such as economic and structural barriers and socio-cultural norms that significantly discourage attendance in formal education.

During the 2019 budget speech, President Muhammadu Buhari articulated the importance of education in fostering development and tackling poverty in Nigeria. To this end, the Federal Government's educational stance as reflected by its proposed budget in 2019, emphasized on "Every Child Counts". This is premised on a national educational system that encourages digital literacy, imparts functional skills to children, ensures re-training of teachers and equipping children from a very young age with modern skills by emphasizing education in science, technology, engineering, arts, and mathematics (STEM). The emphasis on "Every Child Counts" presupposes Federal Government's intent on reducing all existing education inequalities in the country. As respective year's Appropriation Acts reflect the Federal Government's developmental intent, matching Federal Government's proposed financial commitments to its education stance and obligations becomes imperative.

Assuming the federal government, considers as a priority, the objective of respecting the education rights of its citizens as well as its own education obligations, the federal government accordingly embarks on various proactive strategies and policies to achieve this objective. Thus, as asserted by Shultz (2002), the Federal Government's imperative to abide by its educational rights obligations is embodied in its national (and local) policies, and government (public) budgets should, in turn, reflect those policies. The Nigerian Federal Government, in other words, should "put its money where its mouth is". Thus, this assertion becomes the basis for the provision of a critical assessment with regards to how effective and efficient government has been able to fulfill its education rights obligations. This will entail an assessment of Federal Government's budgetary allocations to education from 2016 to 2018 .

This paper provides better insights on the (mis)match between the Federal Government's Appropriations for education in relation to fulfilling its obliga${ }^{1}$ https://www.unicef.org/nigeria/education. 
tions towards education rights. The paper examines the trend in Federal Government's commitment to all forms of education; pre-primary \& nursery, primary, secondary, tertiary, special needs education and nomadic education. This trend analysis presents a holistic representation of proposed expenditure to each level of education. The paper further examines if the budget of Nigeria reflects an effort toward "progressive achievement" of the right to Education. This interrogation is premised on the assumption that the budget is a development tool and should, in time, reflect quantifiable developments on each level of education.

Another objective of the paper is the inquiry of Federal Government's uses of "maximum available resources" in its efforts to improve Educational outcomes. This is premised on understanding the priority placed on educational rights given the demand for limited available resources. Lastly, the paper distills information from the budget data on the attainment of specific guarantees in the $\mathrm{Na}$ tional Policy on Education and Sustainable Development Goals (SDGs). This objective focuses on advocacy with the intent of drawing the attention of the Federal Government to its obligations towards educational rights.

\section{Education as a Right in Nigeria}

The right to education for every child in Nigeria is a fundamental right. This right is guaranteed and recognized internationally and within Nigeria. Internationally, the right to education for every child in enshrined in various international human rights instruments with the provisions made in conventions that guarantee the right to education for every child. The United Nations Declaration on the rights of the Child ${ }^{2}$ and the Convention on the Rights of the Child (CRC) ${ }^{3}$ represent the foundation for the legal basis and protection for the right to education, especially as it concerns basic-primary and secondary-education. Articles 28 and 29 of the CRC recognizes the right of the child to education, with a view to achieving this right progressively and on the basis of equal opportunity. Thus, Article $28(1-3)$ mandates state parties to ensure the following; primary education being free and compulsory to all; encourage different forms of secondary education with a view to promote and make accessible vocational education, higher education and offering financial assistance; encourage attendance and reduce dropout rates; ensure school discipline in accordance with the child's human dignity; and eliminating ignorance and illiteracy.

Other international instruments that promote the right of the child to education and which the Nigerian Federal Government has ratified include United Nations Education, Scientific, and Cultural Organization's (UNESCO) convention against Discrimination in Education $(\mathrm{CDE})^{4}$, the International Labour Organi-

\footnotetext{
${ }^{2}$ Adopted in 1959, this represents the United Nations rights instrument with regards to the child as being vulnerable.

${ }^{3}$ Adopted and opened for signature, ratification and accession by General Assembly resolution 44/25 of 20 November 1989 in relation to the necessity of the Declaration on the rights of the Child.

${ }^{4}$ Adopted by the General Conference at its eleventh session, Paris, 14 December 1960.
} 
zation Convention (No. 107) on the Indigenous and Tribal Population ${ }^{5}$, and The African Charter on the Rights and Welfare of the Child ${ }^{6}$. Articles 1, 2, of UNESCO's CDE focus on tackling any form of discrimination (in the form of access to, substandard, unequal, and unfavorable conditions for education) in education and considers such discrimination a violation of fundamental human rights. In Article 3, 4 and 5, the CDE stipulates the responsibilities of the State in ensuring that the right of every child to free and compulsory education is not violated.

According to the International Lbour Organization (ILO, 2019, September 14), the International Labour Organization Convention (No. 107) on the Indigenous and Tribal Population focuses on safeguarding sub-groups that have not integrated fully, into the national community. These sub-group's social, economic and cultural characteristics may hinder them from benefiting from their fundamental human rights, including the right to education. As such, Article 6 of the ILO convention (No. 107) prioritizes the improvement of the education levels of such sub-group, while Article 21 to 26 allows for improving education opportunity, adapting education programmes to socio-economic norms of the sub-group.

The African Charter on the Rights and Welfare of the Child mandates members of the African Union (AU) to recognize the rights of the child to education. In Article 11 of the charter, the $\mathrm{AU}$ expressly recognizes that every child has a right to education, the opportunity to develop individual talents, personality and abilities to their fullest (African Union, 2019, December 23). The Charter mandates respective member states to embark on special measures to ensure equal access to education for all, especially for the girl child, the gifted and disadvantaged children (focus on children living with disabilities).

In the Nigerian case, any reference to education as a right must emanate from the constitution of the Federal Republic of Nigeria (CFRN) 1999 as amended, due to the constitution being the ground norm. In Sections 33 - 46 of Chapter IV of the CFRN 1999 lists certain rights, with these rights being guaranteed and enforceable (Welch Jr., 2001). However, with a closer scrutiny of these listed rights, the list is silent on education as a right. Nevertheless, the Constitution makes some educational provisions in Sections 18 of Chapter II of the CFRN 1999, which provides that:

“1) Government shall direct its policy towards ensuring that there are equal and adequate educational opportunities at all levels. 2) Government shall promote science and technology. 3) Government shall strive to eradicate illiteracy; and to this end Government shall as and when practicable, provide

${ }^{5}$ Convention concerning the Protection and Integration of Indigenous and Other Tribal and Semi-Tribal Populations in Independent Countries (Entry into force: 02 Jun. 1959) Adoption: Geneva, 40th ILC session (26 Jun. 1957), Status: Outdated instrument (Technical Convention). Convention currently opens for denunciation: 02 Jun. 2019-02 Jun. 2020.

${ }^{6}$ Developed and adopted by the Organization of African Unity (OAU) now African Union (AU) in 1990. 
a) free, compulsory and universal primary education; b) free secondary education; c) free university education; and d) free adult literacy programme".

Despite this educational provision in section 18 of the CFRN 1999, the problem which persists, as argued by Folorunsho et al. (Folorunsho, Kamaldeen, \& Abdulraheem, 2014), is that while the provisions in Section 33 - 46 of the CFRN 1999 have legal rights conferred on them, the provision in Section 18 of the CFRN 1999 do not. The list of rights in Chapter IV of the Constitution are inviolable and are justiciable with redress being sought in a court of law if violated. However, there are no legal preferences in Section 18 to which the constitution makes some provision for education. Thus, tagging education as a fundamental objective rather than a fundamental right in the Nigerian constitution is a major source of concern regarding what constitutes the Federal Government's obligation towards education rights of the child and what actions are available when these obligations are neglected.

Although there are no protection and guarantee of education rights by the Nigerian constitution, other enabling Acts-the Child's Right Act (CRA), 2003 and the Compulsory, Free Universal Basic Education Act, 2004-were established to tackle issues regarding the overall wellbeing and protection of the $\mathrm{Ni}$ gerian Child. Unlike in Nigeria's 1999 Constitution, the CRA aims at enacting into law the ideologies as encapsulated in the Conventions on the Rights of the Child and the African Charter on the Rights and Welfare of the Child and consolidating all laws relating to children into a single legislation (UNICEF, 2007). Section 15 of the CRA guarantees the Nigerian child to free, compulsory and universal primary education. This is not in conformity with the constitution, and in the instance of legal redress, the provisions of the CRA are subject to the constitution.

The CRA Act clearly places the responsibility of the provision of Section 15 on the parent, guardian, persons in custody of the child and the government. On the other hand, while the Act penalizes a parent, guardian or persons in custody of the child in violation of Section 15 (2) of the Act, the Act does not provide for such penalties in regards to the instance where the government violates Section 15 (2). The CRA Act is also lacking in provisions stipulating the government's role in ensuring education is made available, accessible, affordable and adaptable to the Nigerian Child. In corroboration with the CRA Act, the Compulsory, Free Universal Basic Education Act, 2004 establishes the Federal government's role in the provision of compulsory free basic education. Section 1 of the UBE Act expressly defines the Federal Government's interventions as "only be an assistance to the States and Local Governments". However, in remaining consistent with the CRA, the UBE Act also failed to provide for any form of legal redress in the instance of Federal Government's breach of its provisions.

\section{Literature Review}

There is a vast array of literature on the challenges of the Nigerian education 
sector, with challenges being documented for the various levels of education. For example, Aluede et al. (Aluede, Idogho, \& Imonikhe, 2012) found that carrying capacity and inadequate public financing were important factors limiting access to education. Similarly, Asiyai (2013) proposed for the increased spending in higher education as the quality of higher education in Nigeria is below international standard. With regards to Persons Living with Disabilities (PwD), Ajuwon (2008) advocated for developing a positive policy outlook towards PWDs, as non-implementation of the National Policy on Special Education Needs remains a germane challenge. Comfort (2012) noted that despite the change in policy focus for Vocational and Technical Education (VTE) in Nigeria, it is the non-implementation of these policies that pose as the major challenge. This assertion on the challenges of VTE is corroborated by Uwaifo (2010) who argued that poor funding and inadequate facilities remain the major challenge. With regards Universal Basic Education (UBE), Labo-Popoola (Labo-Popoola, Bello, \& Atanda, 2009) identified funding and policy implementation of the UBE as the major constraints. Lastly, Unachukwu (2009) also identified inadequate funding, non-cohesive policy framework and entrepreneurial attitude as the major challenges to entrepreneurial education in Nigeria.

A common factor from the reviewed literature on the challenges of education in Nigeria is the problem of inadequate funding and implementation of policies. These highlighted factors underscore the necessity for conducting this study, as it places a primary focus on the funding to the education sector and how this funding is appropriated to achieve the federal government's education obligations. Matching budgets with developmental outcomes is an important policy pre-requisite, which validates the prioritization and intent of the Federal Government's development objective. However, as argued by Obadan (2003), The Nigerian budget has hardly served as an effective tool for promoting development, with emphasis on the increasing divergence between resource allocation and reality planning.

Budgeting for sub-sectors of the economy or for specific demographic categorization of the society has always attracted challenges, mainly due to its complexity and the nature of scarce financial resources. For example, Stotsky (2007) evaluated the nature of gender budgeting, with a focus on budgeting programs and their effects on women. He found that, while the convention in analyzing the effects of budgeting programs on women is through expenditure effects and revenues effects (Budlender, Elston, Hewitt, \& Mukhopadhyay, 2002), the dynamics and interconnectivity between each sector, sub-group and demographic category of the nation, does not allow for a complete assessment of these effects. Another challenge as proffered by Sample (1992) is the problem of incremental budgeting. In such cases, lack of planning, non-prioritization of the sector, and the dearth of political will to priorities these sectors, will lead to consecutive incremental budgets every year, without any logical match between these budgets and development objectives in these sectors. Especially for sectors and sub-groups of the nation. This sentiment is also shared by both Jhamb, Mishra, and Sinha 
(2013) and Diokno (1999), with both studies noting that while government promotes development objectives, programs to achieve these objectives had their budgets cut in consecutive years. The study reemphasized that the budget process is expected to reflect government's commitment to its already established obligations.

Civil Society Organizations (CSOs) play an important role in advocacy, which ensures greater accountability in how national governments promote socio-economic development and human rights through its budgeting process Robinson (2006). Pantin, Ramjattan, and Francis (2010), Pereznieto, Reddy, \& Mayuri (2007) and the Children's Budget Unit (Children's Budget Unit, 2003), all agreed that CSOs could influence national budgets by providing sectoral trend analysis on budgets that reflect the re-prioritization towards children; improvement of service delivery to children; and assessing governments budget priority to children using indicators.

In summary, the reviewed literature underscores the importance of budgetary appropriations on achieving development outcomes. However, most studies conducted for Nigeria focused more on eliciting the impact of budgetary appropriations (or its changes) to expected progressive development in specific sectors of the Nigerian economy. This paper intends to contribute to the literature by providing an assessment of Federal Governments commitments through its budgetary appropriations, with the aim of ensuring accountability and advocacy, in meeting its educational obligations. The premise of using the budget is hinged on the theoretical expectation of the budget being a developmental tool.

\section{Methodology}

The paper employed a Budget Analysis Framework ${ }^{7}$ in assessing the Federal Government's financial commitment to achieving already established fundamental educational rights. This method, albeit non-conventional, centers on three strategic questions as posed by the paper. Thus, the methodology adopted considers educational rights obligations with the objective of assessing if the budgets reflect any preference for progressive achievements of the right to education, do budgetary appropriations apply the maximum use of available resources to improve educational rights, and how have budgetary appropriations matched specific educational right guarantees? These questions are addressed using the Nigerian Appropriation Acts from 2016 through 2018.

With regards to the progressive achievement of the right to education, the methodology focuses on budgetary expenditure for education as a whole. Inflation adjusted budgeted expenditure are used to capture the real monetary value of expenditure. A disaggregated expenditure trend for basic education

\footnotetext{
${ }^{7}$ The Budget analysis framework to be used is based on the guidelines of Dignity Counts. See Fundar-Centro de Análisis e Investigación, International Human Rights Internship Program and International Budget Project (2004). Dignity Counts. A Guide to Using Budget Analysis to Advance Human Rights. Fundar.
} 
(pre-primary \& nursery, primary), secondary, tertiary, special needs education and nomadic education (all adjusted for inflation) are presented. A contrast of the disaggregated expenditure trend with changes in the allocation to the education sector, highlights possible explanations for such changes. An analysis of per capital expenditure for education captures possible disparities, with emphasis on advocating more resources (or less) for various educational levels.

With regards to the use of maximum available resources to meet its educational rights obligations, the methodology used in the paper analyses the percentage of spending in education (and its levels) relative to GDP, total government spending and revenue. This ratio would reflect the priorities of available resources towards the attainment of government's educational obligations. A comparison of relative shares of each variable to Federal government's spending and revenue envelopes is conducted. This form of comparison aims at providing a snapshot of government's priority areas/sectors. A further comparison of the variation between, budgeted expenditures and utilized expenditures for the education sector as well as other sectors gives a good assessment of government's use of its maximum available resources in compliance with its education obligations.

There are noteworthy limitations to the use of this methodology. Budget analysis framework may not provide answers to political and philosophical questions. Schuftan (2005) highlighted this limitation by asserting that the method may provide answers to what has been or is being spent by the government, but may not provide answers on what should be spent. In this sense, the application of budget analysis is restricted to the dictates of positive economics. Additionally, a cursory look at the budget does not indicate the effectiveness and efficiency in implementation of the budget. Thus, the practice of budget analysis cannot replace actual field observations on the operationalization of the budget. Lastly, inferences are drawn from any specific sector's budget analysis complemented with information about that sector. It is this corroboration of information from the budget and sector specific characteristics that provide a dynamic resource for driving advocacy. Another important limitation of this study is the dearth of available data on actual expenditure. Getting the needed data on actual government expenditure is saddled with bureaucratic processes that make it difficult to assess such information. On this note, the paper would use actual education expenditure where available.

In assessing progressive achievements, the data used include, education expenditures drawn from 2016, 2017, and 2018 Appropriation Acts of the Federal Republic of Nigeria ${ }^{8}$. The expenditure figures are adjusted for inflation ${ }^{9}$ and disaggregated by different tiers of educational levels ${ }^{10}$. Data on education enrollment was derived from 2018 Nigerian Digest of Education Statistics, Ministry of Education, while data for Senior Secondary School Performance was gotten from

\footnotetext{
${ }^{8}$ Sourced from http://www.budgetoffice.gov.ng/.

${ }^{9}$ Sourced from http://statistics.cbn.gov.ng/cbn-onlinestats/QueryResultWizard.aspx.

${ }^{10}$ Sourced from https://www.ubec.gov.ng/data/.
} 
West African Examination Council (WAEC). Unemployment data were sourced from the National Bureau of Statistics.

\subsection{Assessing Federal Government's Commitment to Progressive Achievement of the Right to Education}

In this section, the paper provides a budget analysis of the education sector with reference to assessing the Federal Government's financial commitments to progressive achievements of the right to education. Here, the focus of analysis is on the direction and magnitude of progress towards established education obligations. The first point of analysis is to show how the inflation-adjusted budgeted expenditure for education has changed within the period of interest (Table 1). Budgeted education expenditure grew by $36 \%$ from $\$ 480.28$ billion in 2016 to \#651.23 billion in 2018. In sharp contrast, when adjusted for inflation, budgeted expenditure for education increased by $3.8 \%$ from $\$ 425.13$ billion in 2016 to $\$ 431.02$ billion in 2018. Although, there seems a significant increase in the appropriation for education in nominal terms, in real terms, such increase is eroded. When the share of education to total budgetary expenditure is considered, the assertion becomes evident. Figure 1 clearly indicates that the share of education to total expenditure has fallen from 8\% in 2016 to 7\% in 2018.

In order to have a better idea of why the share of education to total expenditure fell in 2017 and the major contributors to its slight increase in 2018, the paper examines appropriated expenditure by different levels of education. This disaggregated view presented in Table 2, reflects respective changes in both budgeted and inflation-adjusted budgeted expenditures. From Table 2, the levels of education that contributed to the decline in budgeted education expenditure

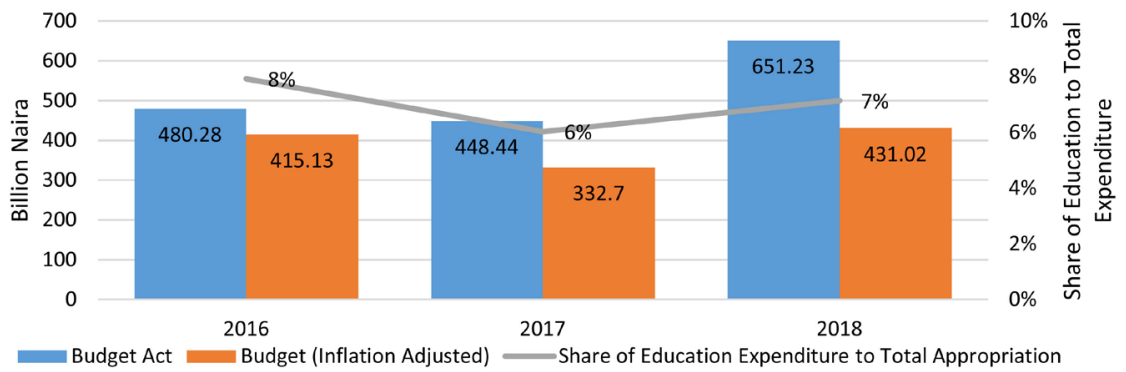

Figure 1. Budget, inflation-adjusted budget and share of education expenditure. Source: 2016, 2017 and 2018 Appropriation Acts.

Table 1. Budget, inflation-adjusted budget and share of education expenditure.

\begin{tabular}{cccc}
\hline Budget Act & $\begin{array}{c}\text { Budget Billion } \\
\text { (Inflation-Adjusted) }\end{array}$ & $\begin{array}{c}\text { Share of Education } \\
\text { Expenditure to Total Appropriation }\end{array}$ \\
\hline 2016 & 480.28 & 415.13 & $8 \%$ \\
2017 & 448.44 & 332.7 & $6 \%$ \\
2018 & 651.23 & 431.02 & $7 \%$ \\
\hline
\end{tabular}

Source: 2016, 2017 and 2018 appropriation acts. 
Table 2. Changes in budgeted expenditure for various education levels Billion).

\begin{tabular}{|c|c|c|c|c|c|c|}
\hline $\begin{array}{l}\text { Education by } \\
\text { Classification }\end{array}$ & & 2016 & 2017 & $\begin{array}{c}\text { \% Change } \\
\text { in } 2017\end{array}$ & 2018 & $\begin{array}{c}\text { \% Change } \\
\text { in } 2018\end{array}$ \\
\hline \multirow[b]{2}{*}{ Headquarters } & Budget & 9.87 & 11.02 & $11.7 \%$ & 25.82 & $134.3 \%$ \\
\hline & $\begin{array}{c}\text { Budget } \\
\text { (Inflation-Adjusted) }\end{array}$ & 8.53 & 8.18 & $-4.2 \%$ & 17.09 & $109.0 \%$ \\
\hline \multirow[b]{2}{*}{ UBE } & Budget & 77.11 & 125.00 & $62.1 \%$ & 109.06 & $-12.7 \%$ \\
\hline & $\begin{array}{c}\text { Budget } \\
\text { (Inflation-Adjusted) }\end{array}$ & 66.65 & 92.74 & $39.1 \%$ & 72.19 & $-22.2 \%$ \\
\hline \multirow[b]{2}{*}{ Secondary } & Budget & 39.90 & 48.21 & $20.8 \%$ & 52.63 & $9.2 \%$ \\
\hline & $\begin{array}{c}\text { Budget } \\
\text { (Inflation-Adjusted) }\end{array}$ & 34.49 & 35.77 & $3.7 \%$ & 34.83 & $-2.6 \%$ \\
\hline \multirow[b]{2}{*}{ Tertiary } & Budget & 310.96 & 354.61 & $14.0 \%$ & 402.09 & $13.4 \%$ \\
\hline & $\begin{array}{c}\text { Budget } \\
\text { (Inflation-Adjusted) }\end{array}$ & 268.78 & 263.09 & $-2.1 \%$ & 266.13 & $1.2 \%$ \\
\hline \multirow{2}{*}{$\begin{array}{l}\text { Vocational } \\
\text { \& Technical }\end{array}$} & Budget & 2.47 & 3.41 & $38.1 \%$ & 3.07 & $-10.0 \%$ \\
\hline & $\begin{array}{c}\text { Budget } \\
\text { (Inflation-Adjusted) }\end{array}$ & 2.13 & 2.53 & $18.5 \%$ & 2.03 & $-19.7 \%$ \\
\hline \multirow[b]{2}{*}{ Nomadic } & Budget & 0.79 & 1.01 & $28.2 \%$ & 1.74 & $72.3 \%$ \\
\hline & $\begin{array}{c}\text { Budget } \\
\text { (Inflation-Adjusted) }\end{array}$ & 0.68 & 0.75 & $10.0 \%$ & 1.15 & $53.7 \%$ \\
\hline \multirow[b]{2}{*}{ Literacy } & Budget & 2.23 & 2.06 & $-7.6 \%$ & 1.74 & $-15.5 \%$ \\
\hline & $\begin{array}{c}\text { Budget } \\
\text { (Inflation-Adjusted) }\end{array}$ & 1.93 & 1.53 & $-20.7 \%$ & 1.15 & $-24.6 \%$ \\
\hline Teacher \& & Budget & 3.33 & 3.45 & $3.6 \%$ & 5.22 & $51.3 \%$ \\
\hline $\begin{array}{l}\text { Teacher's } \\
\text { Training }\end{array}$ & $\begin{array}{c}\text { Budget } \\
\text { (Inflation-Adjusted) }\end{array}$ & 2.88 & 2.56 & $-11.1 \%$ & 3.45 & $35.0 \%$ \\
\hline
\end{tabular}

Source: 2016, 2017 and 2018 appropriation acts.

are; Tertiary education fell by $2.1 \%$ in real terms (even though nominal budget increased by $14 \%$ ); Adult literacy education fell by $-20 \%$; and Teacher's Training fell by $-11.1 \%$ (even though nominal budget increased by $3.6 \%$ ). In 2018 , budgeted expenditure for education increased by $1 \%$ point from $6 \%$ in 2017 , but did not return to its 2016 levels. Adult literacy education, UBE, secondary education, and vocational and technical education, all experienced significant reductions in their inflation-adjusted budgets for 2018.

Another finding from the disaggregated budgeted figures, is the divergence in the direction and magnitude of changes, between nominal and inflation-adjusted appropriations. From Table 2, while Federal Government's Commitments to tertiary education increased significantly in nominal terms, when adjusted for inflation, the commitment stagnated. Thus, while the paper acknowledges that Federal Government concentrates a significant bulk of its education financing commitments to tertiary education, in real terms, this commitment has stag- 
nated and does not indicate progressive achievements. The same conclusions on the stagnation of financial commitments apply to secondary education and Headquarters, Vocational and Technical education, and Teachers Training (Table 2).

The analysis of the relative shares revealed that, budgeted expenditure for education concentrates on tertiary education as compared to other levels of education (see Figure 2). In all years reviewed, the share of budgeted expenditure for tertiary education was more than $60 \%$ of total budgeted expenditure for education sector. Irrespective of the disparity in relative shares, Federal Government's commitment leaned more towards UBE, Secondary education and Tertiary education. All three levels of education accounted for above $80 \%$ of the total education budget in 2016 through 2018.

The Paper also performed a per capita analysis ${ }^{11}$ of the budgeted education expenditure. Figure 3 shows the population of student/pupils covered by the budget. Enrollment figures show that enrollment in UBE (early childhood education, pre-nursery, primary and junior secondary education) had the highest figures in comparison to other educational levels.

However, what is of importance is the per capita expenditure for each education level. Figure 4 shows the trend in per capita expenditure for UBE. The

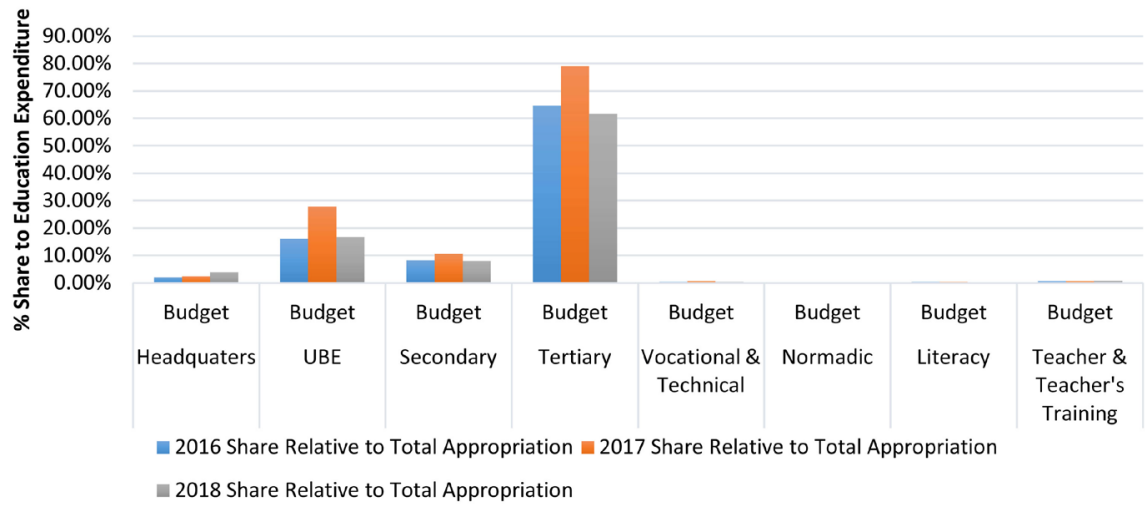

Figure 2. Relative shares of expenditure in various education levels to total education expenditure. Source: 2016, 2017 and 2018 appropriation acts.

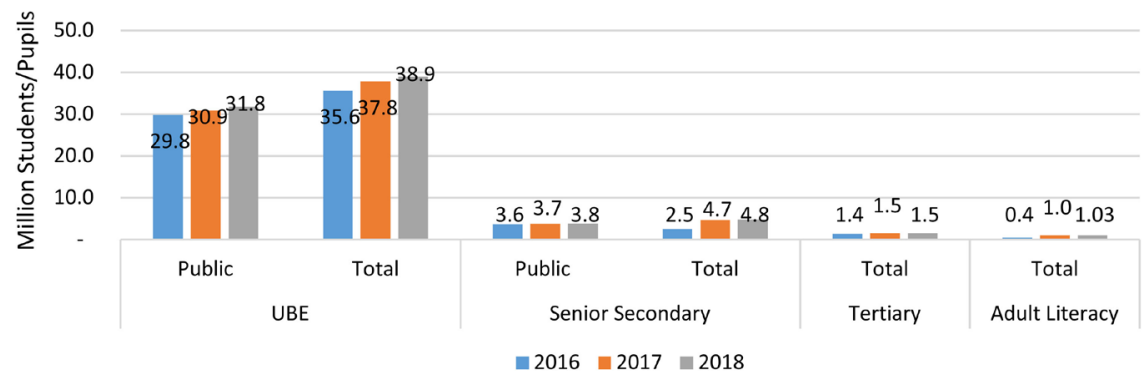

Figure 3. Enrollment figures by education levels. Source: 2018 Nigerian digest of education statistics, ministry of education.

\footnotetext{
${ }^{11}$ In this analysis, per capita figures are generated by dividing the budgeted expenditure for a specific level of education by the total population of student/pupils expected to be covered by the budgeted expenditure.
} 


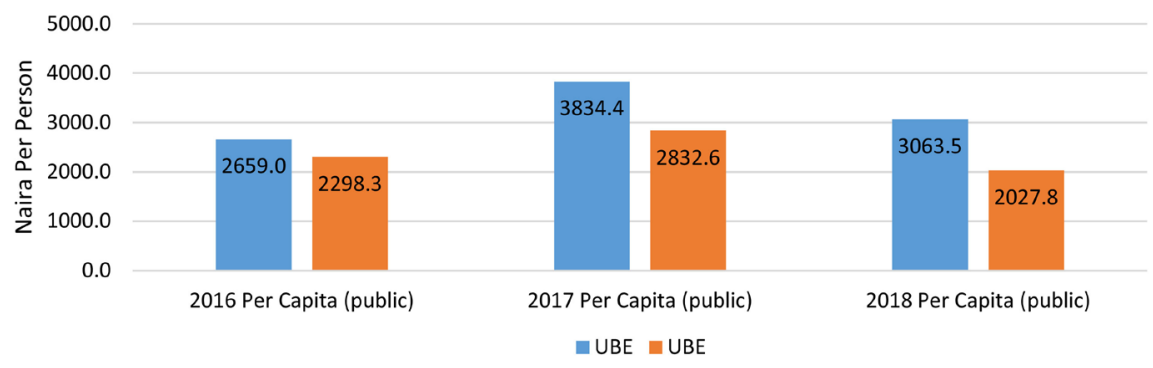

Figure 4. Per capita expenditure for UBE. Source: Compiled by author from 2016, 2017 and 2018 appropriation acts.

Federal Government intends to spend, in real terms as in 2018, 2027.8 on each pupil captured by UBE. This represents a decrease of $11.77 \%$ from $\$ 2298.3$ budgeted in 2016. This reduction does not reflect a positive commitment stance towards improving UBE coverage, as the number of out-of-school children in Nigeria increased from about 10 million in 2016 to 13.2 million in 2018. Given the objective of UBE to reduce the incidence of out-of-school children, then the actual per capita expenditure for UBE should reflect all children expected to be covered by UBE and not only students enrolled under UBE. Thus, we generate per capita expenditure by dividing the budgeted expenditure for UBE by the total population of student/pupils expected to be covered (both in-school and outof-school children). In this sense, the Federal Government's real financial commitment (accounting for all children of school age) to reducing out-of-school children in 2016 will be $\$ 1674.62$ per pupil and $\$ 1604.22$ per pupil in 2018. A significant reduction of $4 \%{ }^{12}$.

Going by 2018 financial commitments, the Federal government is to commit, at least additional 40.43 billion ${ }^{13}$ to carter for all out-of-school children. Spread across five years, the Federal Government's financial commitment to reducing out-of-school children should average $\$ 8.08$ billion (yearly increase of $7.41 \%$ ) in additional funding. Sadly, UBE's inflation-adjusted budget in the 2019 Appropriation Act reduced by $15 \%$ to $\$ 69.24$ billion. Thus, Federal Government's financial commitments do not reflect progressive achievements in achieving zero out-of-school children through its Universal Basic Education.

Although nominal per capita expenditure for secondary school education increased over the period 2016 to 2018, in real terms, per capita expenditure reduced from $\$ 4155.08$ in 2016 to $\$ 3518.56$ in 2018 , representing a $15.31 \%$ reduction. Is the Federal Government spending less on secondary education? In Figure 5, the real per capita expenditure for secondary education is also on the decline. When comparing real per capita expenditure with the performance in the Secondary School Certificate Examinations, a clear indication of the extent of progressive achievement (or not) is made. Within the period 2016-2018, the

${ }^{12}$ This figures are derived by first adding in-school and out-of-school children for each year. Per capita is derived by dividing the budget for UBE by the sum of in-school and out-of-school children. Here, out-of-school children is 13.2 million.

${ }^{13}$ Multiply 2018 per capita figure by 13.2 million out-of-school children. 


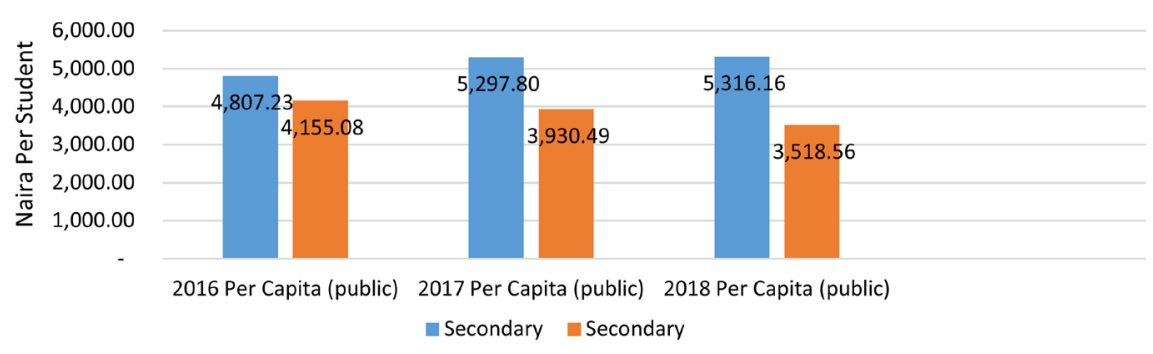

Figure 5. Per capita expenditure for secondary education. Source: Compiled by author from 2016, 2017 and 2018 appropriation acts.

fraction of candidates who had meet partial requirements for gaining entrance into the university reduced from $56 \%$ in 2016 to $49.8 \%$ in 2018 . On the other hand, the number of candidates who did not meet these requirements increased from $43.5 \%$ in 2016 to $50.2 \%$ in 2018 (see Table 3). This change in trend reflects a $6.8 \%$ point increase in candidates not meeting the requirement.

The increase in candidates who did not meet the SSCE requirement indicates that, over the period 2016-2018, where the Federal Government had committed about $\$ 105$ billion (an average of $\$ 35$ billion per year), the number of candidates who did not meet the requirement to transition into the university increased by an estimated average of 106,324 candidates. In real terms, we estimate the cost of this non-progressive achievement by combining the average per capita expenditure for secondary school and the number of candidates who did not meet the SSCE requirement. This translates to $\$ 411.27$ million. Thus, for the period 2016 to 2018, the Federal Government has committed the sum of $\$ 411.27$ million (about $1.17 \%$ of the total secondary education budget) to students who would not meet the requirement for admission into a university. This estimate is overly conservative as UBE already covers junior secondary education. Adjusting for this, the per capita expenditure and the estimated expenditure for candidates who did not meet the requirement would be higher. Although this paper recognizes that this finding may not necessarily capture other important structural and policy issues governing secondary school education, this finding only gives insight to the adherent Federal Government's financing inadequacies. Premised on this financing inadequacy, the paper proposes an enabling investment environment for the private sector.

However, the current status of non-public schools in Nigeria suggests that there is a very limited accountability structure, with the need for the Federal Ministry of Education providing clearer supervisory and management approach in order to ensure non-public schools align with medium to long term educational objectives. For non-public schools, private and religious schools provide a significant proportion of enrollments. Although both private and religious schools have been associated with lower unit costs relative to public schools, the UBE Act 2004 limits its operationalization to only public schools, neglecting the potentials of the relative cost-effectiveness of private and religious schools in ensuring improved access to quality education (World Bank Group, 2015). 
Table 3. Performance in secondary school certificate examinations.

\begin{tabular}{cccc}
\hline Year & $\begin{array}{c}\text { Total SSCE Candidates who } \\
\text { Met Requirement }{ }^{14}\end{array}$ & $\begin{array}{c}\text { Total SSCE Candidates who } \\
\text { did not Meet Requirement }\end{array}$ & $\begin{array}{c}\text { Total Number } \\
\text { of Candidates }\end{array}$ \\
\hline \multirow{2}{*}{2016} & 878,040 & 674,718 & $1,552,758$ \\
& $(56.5 \%)$ & $(43.5 \%)$ & \\
2017 & 923,846 & 635,316 & $1,559,162$ \\
& $(59.3 \%)$ & $(40.7 \%)$ & $1,578,846$ \\
2018 & 786,016 & 858,424 & \\
\hline
\end{tabular}

Source: West African Examination Council (WAEC). Figures in brackets represent proportional shares.

In assessing Federal Government's commitment to tertiary education, the data revealed that in both nominal and real terms, the per capita spending for each tertiary student has consistently declined from 2016 to 2018 (Figure 6). Although tertiary education has the largest share of the total education budget and per capita financial commitments, it does not have the largest number of enrolled students ${ }^{15}$. This signifies that the Federal Government places a higher priority on tertiary education as compared to any other level of education with higher enrollment rates. A contrary argument would be that tertiary education is more expensive than other levels of education, therefore necessitating its significantly larger financial commitments.

From an outcome perspective, tertiary education should improve human capital development (Montegro and Patrinos, 2013), have prospects for inducing growth through innovations by skilled workers (Romer, 1986) (Romer, 1990), and have the highest rate of return on investment when compared to other levels of education (Montegro and Patrinos, 2013). However, the increase in Federal Government commitments to tertiary education may be associated with the increase in youth labour force, but with a detrimental incidence of increasing youth unemployment (Table 4). From this outcome perspective, the financial commitments may not reflect progressive achievements in tertiary education. However, this assertion is subject to the inference that tertiary education should lead to the creation of more jobs through innovations and entrepreneurship.

\subsection{Assessing Federal Government's Commitment to Its Maximum Use of Available Resources}

This assessment focuses on determining the government's prioritization of its financial resources towards essential education needs. Thus, the paper provides the fraction of total education appropriations to the Gross Domestic Product (GDP), Revenue and retained revenues. The fraction of education appropriation to GDP reflects how much of the total economy's value is spent on education. With regards revenue, of the paper uses both total revenue and retained revenue,

\footnotetext{
${ }^{14}$ Five credits including mathematics and English.

${ }^{15}$ Primary education.
} 


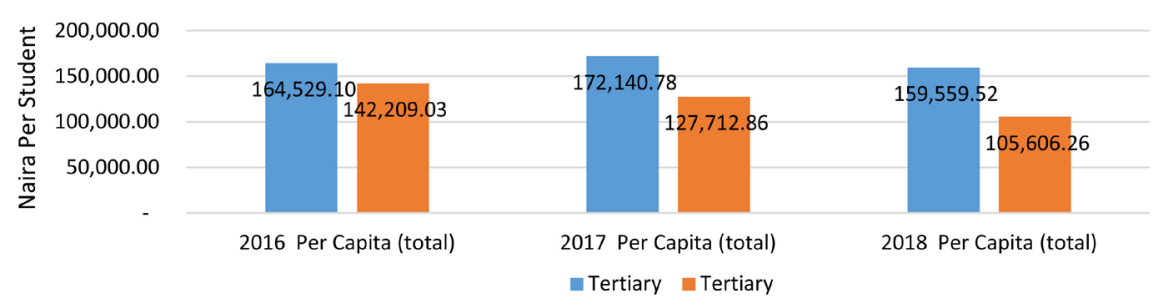

Figure 6. Per capita expenditure for tertiary education. Source: Compiled by author from 2016, 2017 and 2018 appropriation acts.

Table 4. Youth unemployment and spending on tertiary education.

\begin{tabular}{ccccc}
\hline Period & $\begin{array}{c}\text { Youth } \\
\text { Labour Force }\end{array}$ & $\begin{array}{c}\text { Youth } \\
\text { Unemployment }\end{array}$ & $\begin{array}{c}\text { Youth } \\
\text { Unemployment Rate }\end{array}$ & $\begin{array}{c}\text { Spending on Tertiary } \\
\text { Education (\#illion) }\end{array}$ \\
\hline 2016Q4 & $40,739,520$ & $7,900,985$ & 19.39391 & 310.96 \\
2017Q4 & $42,630,874$ & $11,332,739$ & 26.58341 & 354.61 \\
2018Q4 & $44,229,418$ & $13,145,708$ & 29.72164 & 402.09 \\
\hline
\end{tabular}

Source: National Bureau of statistics (2019). Youth is defined within the age bracket 15 - 34.

as they reflect a spending envelope through which the Federal Government intends to achieve its development objectives. Both GDP and Revenue ratios provide an index of assessing the prioritization of Federal Government's intent on meeting its educational obligations.

From Figure 7, the average share of budgeted spending on education to GDP from 2016 to 2018 is a little above $0.45 \%$, less than $1 \%$ of the total value of the Nigeria's GDP. While this fraction reduced in the period 2016 to 2017 (also applicable for revenue and retained revenue), the fraction of less than $1 \%$ of GDP indicates that education seems to be less prioritized when measured against the value of all resources available in Nigeria. A comparative analysis between the shares of budgeted spending on education with other sectors, buttresses this point.

In Table 5 and Table 6, the paper presents a comparison between the shares of budgeted spending on education with ESC right and Non-ESC right. ESC rights include the human right to work, the right to an adequate standard of living, including food, clothing, and housing, the right to physical and mental health, the right to social security, the right to a healthy environment, and the right to education (King, 2003). Specifically, Table 5 compares relative shares among other ESC rights sectors-health and water resources, while Table 6 compares relative shares among non-Esc right sectors-finance and budget \& planning. Intuitively, issues relating to education, water resources and health are highly correlated in developing economies, and as such, stand-alone policies are ineffective.

Nevertheless, a comparative analysis of each sector's relative share reveals that health, education, and water resources have an average relative share of $0.27 \%$, $0.46 \%$ and $0.08 \%$ to GDP respectively over the period 2016 to 2018 . This is a 


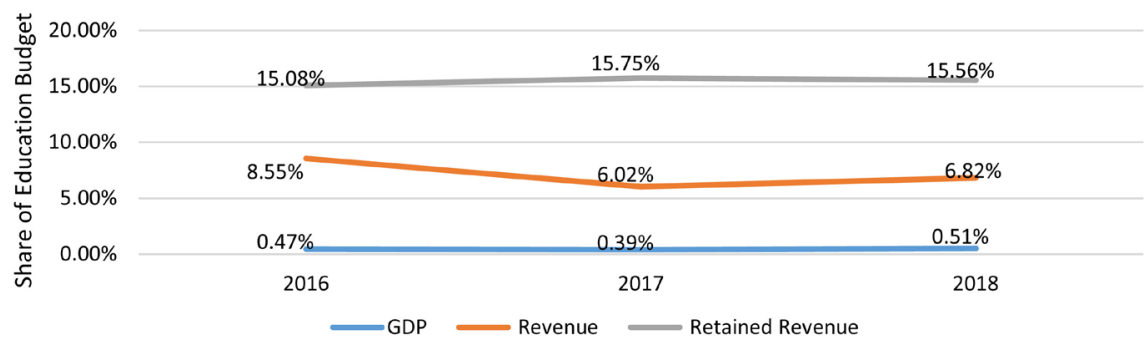

Figure 7. Share of education appropriation to GDP, revenue and retained revenue. Source: Compiled by author from 2016, 2017 and 2018 appropriation acts and respective Medium Term Expenditure Framework (MTEF).

Table 5. Comparison of shares of budgeted spending on education with other Economic, Social and Cultural (ESC) rights sectors.

\begin{tabular}{cccccccccc}
\hline & \multicolumn{3}{c}{ GDP } & & \multicolumn{3}{c}{ Revenue } & \multicolumn{3}{c}{ Retained Revenue } \\
\cline { 2 - 9 } & Health & Education & Water & Health & Education & Water & Health & Education & Water \\
\hline 2016 & $0.25 \%$ & $0.47 \%$ & $0.05 \%$ & $4.45 \%$ & $8.55 \%$ & $0.95 \%$ & $7.85 \%$ & $15.08 \%$ & $1.67 \%$ \\
2017 & $0.28 \%$ & $0.39 \%$ & $0.08 \%$ & $3.86 \%$ & $6.02 \%$ & $1.24 \%$ & $10.09 \%$ & $15.75 \%$ & $3.25 \%$ \\
2018 & $0.28 \%$ & $0.51 \%$ & $0.12 \%$ & $3.73 \%$ & $6.82 \%$ & $1.62 \%$ & $8.52 \%$ & $15.56 \%$ & $3.71 \%$ \\
\hline
\end{tabular}

Source: Compiled by Author from 2016, 2017 and 2018 appropriation acts and Office of Accountant General of the Federation (OAGF).

Table 6. Comparison of shares of budgeted spending on education with non-Economic, Social and Cultural (non-ESC) rights sectors.

\begin{tabular}{cccccccccc}
\hline & \multicolumn{3}{c}{ GDP } & \multicolumn{2}{c}{ Revenue } & \multicolumn{2}{c}{ Retained Revenue } \\
\cline { 2 - 8 } & Finance Education & $\begin{array}{c}\text { Budget \& } \\
\text { Planning }\end{array}$ & Finance Education & $\begin{array}{c}\text { Budget \& } \\
\text { Planning }\end{array}$ & Finance Education & $\begin{array}{c}\text { Budget \& } \\
\text { Planning }\end{array}$ \\
\hline 2016 & $1.46 \%$ & $0.47 \%$ & $1.13 \%$ & $26.46 \%$ & $8.55 \%$ & $20.43 \%$ & $46.66 \%$ & $15.08 \%$ & $36.02 \%$ \\
2017 & $1.63 \%$ & $0.39 \%$ & $1.20 \%$ & $24.93 \%$ & $6.02 \%$ & $18.30 \%$ & $65.19 \%$ & $15.75 \%$ & $47.84 \%$ \\
2018 & $1.74 \%$ & $0.51 \%$ & $1.45 \%$ & $23.22 \%$ & $6.82 \%$ & $19.46 \%$ & $52.98 \%$ & $15.56 \%$ & $44.41 \%$ \\
\hline
\end{tabular}

Source: Compiled by Author from 2016, 2017 and 2018 appropriation acts and Office of Accountant General of the Federation (OAGF).

combined average share to GDP of $0.81 \%$ for these essential ESC right sectors. For non-ESC rights sectors, the average relative shares to GDP for Finance and Budget \& Planning stood at $1.61 \%$ and $1.26 \%$ respectively for the period 2016 to 2018. This represents a combined average share to GDP of $2.87 \%$ for non ESC rights sectors. From both Table 5 and Table 6, it is clear that the Federal Government prioritizes non-ESC right sectors over ESC rights sectors, as the relative shares of Finance and Budget \& Planning are significantly higher than those of Health and Water Resources. This same inference applies when considering both the relative share of revenue and retained revenue.

\subsection{Result of Analysis}

The budget analysis framework used in this paper focused on assessing Federal 
Government's commitment in achieving its educational obligations as enshrined in established educational rights. To this end, the paper sought to elicit if there have been progressive achievements as well as maximum use of available resources in meeting the Federal Governments educational obligations. While various insights had earlier been mentioned at several points in the paper, it is noteworthy to put them all together.

While the government has increased its financial commitments to the educational sector, when adjusted for inflation, these financial commitments are actually on the decline. It is important for the Federal Government to recognize the importance of real spending power while budgeting for the education sector. This adjustment for real spending mitigates against the situation where financial commitments may seem to be progressing, but in real terms may be declining.

The bulk of Federal Government's financial commitments lean more towards tertiary education relative to other levels of education. It appears that the Federal Government prioritizes tertiary education over other levels of education. This is counter-intuitive, as studies have shown that each level of education is as important as the other (Kieffer, 2010). This assertion is a call for equitable financial commitments, especially for the non-traditional levels of education (Vocational, nomadic, adult literacy and special needs education).

The per capita analysis showed that if the current trend in financial commitment for UBE is sustained, the objective of zero out-of-school children will not be met. Spread across five years, the Federal Government's financial commitment to reducing out-of-school children should average $\$ 8.08$ billion (yearly increase of 7.41\%) in additional funding. Sadly, in the 2019 Appropriation Act, inflation-adjusted budget for UBE was reduced by $15 \%$ to N69.24 billion. Thus, Federal Government's financial commitments do not reflect progressive achievements in achieving zero out-of-school children through its Universal Basic Education.

The average share of budgeted spending on education to GDP from 2016 to 2018 is a little above $0.45 \%$, less than $1 \%$ of the total value of Nigeria's GDP. The fraction of less than $1 \%$ of GDP indicates that education seems to be less prioritized when measured against all the value of resources available to Nigeria.

A comparative analysis of each sector's relative share reveals that health, education, and water resources (ESC sectors) had a combined average relative share to GDP of $0.81 \%$. On the other hand, Finance and Budget \& Planning (non-ESC sectors) averaged relative shares to GDP of $2.87 \%$. It is clear that the Federal Government prioritizes non-ESC sectors over ESC sectors, as it commits more financial resources to non-ESC sectors. This same inference can be drawn using both the relative share of revenue and retained revenue. Given the level of economic development in Nigeria, ESC sectors should be prioritized over non-ESC sectors.

In summary, the findings of the paper suggest that the education sector, which encapsulates an essential right, has not been prioritized by the Nigerian Federal 
Government, unlike in the case of non-essential sectors like administration. For a developing economy, this trend must be discontinued.

\section{Conclusion}

Taken together, the data and analysis of the Federal Government's Commitment to its education rights and obligations indicate that, the Nigerian government may not be meeting up with its educational obligations. The paper focused on financial commitments as captured in the budget from 2016 to 2018, to capture if there have been progressive achievements in these educational obligations and if there has been maximum use of available resources.

From the findings in the paper, the paper provides the following policy implications of the findings. First, there is a need to guarantee adequate and equitable funding for non-traditional and conventional forms of education. The analysis revealed that financial commitments through the budget for Nomadic education, Vocational and Technical education, Adult literacy, and Special Needs Education are not prioritized in the budget. This is not in cognizance with the dearth in educational outputs and outcomes in these levels of education. Thus, the $\mathrm{Na}$ tional Assembly, during the education budget defense, should strongly emphasize the need for more funding for these levels of education.

Although the paper did not focus on an assessment of policy framework guiding each level of education analyzed, the civil society needs to advocate for policy reviews, especially specific policy guiding education funding responsibilities. Pressure (possibly, the use of litigation) should be put on the government when it fails to follow through its educational rights obligations.

There is a need for a guiding framework that stipulates the working relationship between public and non-public schools with the sole objective of improving access to quality education. Given the established unit cost-effectiveness of non-public schools and their respective enrollment capacities, the UBE Act 2004 should include intervention funds specifically for enrolling students from poor households.

As such, any supplementary funding should not be in the form of matching grants, as there are statutory requirements (as stipulated in the UBE Act 2004) attached to such funding, as other sub-national governments may not be able to match these criteria. The funding should be directed at addressing educational imbalances among and within states; incentives to encourage school enrollment and participation-like the school feeding and health programmes; additional and direct funding intervention to states and local governments with established good performance in reducing out-of-school children; and funding directly targeted at Persons Living with Disability and Special Needs Education.

\section{Funding}

This research received funding from the National Institute for Legislative and Democratic Studies, National Assembly, Abuja. 


\section{Conflicts of Interest}

The author declares no conflicts of interest regarding the publication of this paper.

\section{References}

African Union (2019). African Charter on the Rights and Welfare of the Child. African Union. https://au.int/en/treaties/african-charter-rights-and-welfare-child

Ajuwon, P. M. (2008). Inclusive Education for Students with Disabilities in Nigeria: Benefits, Challenges and Policy Implications. International Journal of Special Education, 23, 11-16.

Aluede, O., Idogho, P. O., \& Imonikhe, J. S. (2012). Increasing Access to University Education in Nigeria: Present Challenges and Suggestions for the Future. The African Symposium, 12, 3-13.

Asiyai, R. I. (2013). Challenges of Quality in Higher Education in Nigeria in the 21st Century. International Journal of Educational Planning \& Administration, 3, 159-172.

Auld, E., Rappleye, J., \& Morris, P. (2019). PISA for Development: How the OECD and World Bank Shaped Education Governance Post-2015. Comparative Education, 55, 197-219. https://doi.org/10.1080/03050068.2018.1538635

Ball, S. J. (1998). Big Policies/Small World: An Introduction to International Perspectives in Education Policy. Comparative Education, 34, 119-130.

https://doi.org/10.1080/03050069828225

Budlender, D., Elston, D., Hewitt, G., \& Mukhopadhyay, T. (2002). Gender Budgets Make Cents: Understanding Gender Responsive Budgets. Commonwealth Secretariat.

Children's Budget Unit (2003). Monitoring Government Budgets to Advance Child Rights: A Guide to NGOs. Institute for Democracy.

Comfort, C. (2012). Vocational Technical Education in Nigeria: Challenges and the Way Forward. Business Management Dynamics, 2, 1.

Diokno, M. (1999). A Rights-Based Approach towards Budget Analysis. Washington DC: International Human Rights Internship Program.

Folorunsho, A. H., Kamaldeen, M., \& Abdulraheem, T. A. (2014). Children's Right to Education in Nigeria: Challenges and Solutions. Journal of Public Law and Constitutional Practice, 6, 104-117.

ILO (2019). International Labour Organization. https://www.ilo.org/dyn/normlex/en/f?p=NORMLEXPUB:12100:0::NO::P12100_ILO_ CODE:C107

Jhamb, B., Mishra, Y., \& Sinha, N. (2013). The Paradox of Gender Responsive Budgeting. Economic and Political Weekly, 48, 35-38.

Kieffer, A. (2010). Measuring and Comparing Levels of Education: Methodological Problems in the Classification of Educational Levels in the European Social Surveys and the French Labor Force Surveys. Bulletin of Sociological Methodology/Bulletin de Méthodologie Sociologique, 107, 49-73. https://doi.org/10.1177/0759106310369974

King, J. (2003). An Activist's Manual on the International Covenant on Economic, Social and Cultural Rights. Colombo: Law \& Society Trust.

Labo-Popoola, S. O., Bello, A. A., \& Atanda, F. A. (2009). Universal Basic Education in Nigeria: Challenges and Way Forward. Pakistan Journal of Social Sciences, 4, 614-621.

Montegro, C. E., \& Patrinos, H. A. (2013). Returns to Schooling around the World. Back- 
ground Paper for the World Development Report 2013. Washington DC: World Bank.

Obadan, M. I. (2003). National Development Planning and Budgeting in Nigeria: Some Pertinent Issues. Anderson, IN: Broadway Press.

Pantin, D., Ramjattan, D., \& Francis, J. (2010). Child Responsive Budgeting: The Case of Trinidad and Tobago. Sustainable Economic Development Unit (SEDU) for Small and Island Developing States (SIDS), Department of Economics, University of the West Indies United Nations Children's Fund (UNICEF).

Pereznieto, P., Reddy, G., \& Mayuri, K. (2007). Improving Child-Focused Spending in Local Bodies in Andhra Pradesh. Social Policy, 3.

Psacharopoulos, G., \& Patrinos, H. A. (2018). Returns to Investment in Education: A Decennial Review of the Global Literature. The World Bank. https://doi.org/10.1596/1813-9450-8402

Robinson, M. (2006). Budget Analysis and Policy Advocacy: The Role of Non-Governmental Public Action. Working Paper Series No. 279. Brighton: IDS.

Romer, P. M. (1986). Increasing Returns and Long-Run Growth. Journal of Political Econo$m y$, 94, 1002-1037. https://doi.org/10.1086/261420

Romer, P. M. (1990). Endogenous Technical Change. Journal of Political Economy, 98, 71-102. https://doi.org/10.1086/261725

Sample, V. A. (1992). Resource Planning and Budgeting for National Forest Management. Public Administration Review, 52, 339-346. https://doi.org/10.2307/3110393

Schuftan, C. (2005). Dignity Counts: A Guide to Using Budget Analysis to Advance Human Rights. Social Change, 35, 143-146. https://doi.org/10.1177/004908570503500113

Shultz, J. (2002). Promises to Keep: Using Public Budgets as a Tool to Advance Economic, Social and Cultural Rights. Fundar Centro de Análisis.

Stotsky, J. G. (2007). Budgeting with Women in Mind. Finance and Development, 44, 12-15.

Unachukwu, G. O. (2009). Issues and Challenges in the Development of Entrepreneurship Education in Nigeria. African Research Review, 3, No. 5. https://doi.org/10.4314/afrrev.v3i5.51153

UNICEF (2007). UNICEF Fact Sheet on the Child's Rights Act in Nigeria.

UNICEF (2019). UNICEF Education. https://www.unicef.org/nigeria/education

Uwaifo, V. O. (2010). Technical Education and its Challenges in Nigeria in the 21st Century. International NGO Journal, 5, 40-44.

Welch Jr., C. E. (2001). Protecting Human Rights in Africa: Roles and Strategies of Nongovernmental Organizations. Philadelphia, PA: University of Pennsylvania Press.

World Bank Group (2015). Governance and Finance Analysis of the Basic Education Sector in Nigeria. Report No. ACS14245. 